\title{
Influence of chelating agents on biogenic uraninite reoxidation by Fe(III) (Hydr)oxides
}

\section{Authors: Brandy D. Stewart, Crystal Girardot, Nicolas Spycher, Rajesh K. Sani, and Brent M. Peyton}

NOTICE: This document is the unedited author's version of a Submitted Work that was subsequently accepted for publication in Environmental Science \& Technology, copyright (C) American Chemical Society after peer review. To access the final edited and published work, see http://dx.doi.org/10.1021/es303022p.

Stewart BD, Girardot C, Spycher N, Sani RK, Peyton BM, "Influence of chelating agents on biogenic uraninite reoxidation by $\mathrm{Fe}(\mathrm{III})$ (Hydr)oxides," Environmental Science \& Technology, January 2013 47(1):364-371. 


\title{
Influence of Chelating Agents on Biogenic Uraninite Reoxidation by Fe(III) (Hydr)oxides
}

\author{
Brandy D. Stewart, ${ }^{\dagger}$ Crystal Girardot, ${ }^{\dagger}$ Nicolas Spycher, ${ }^{\dagger}$ Rajesh K. Sani, ${ }^{\S}$ and Brent \\ M. Peyton ${ }^{\dagger}, *$
}

Chemical and Biological Engineering and Center for Biofilm Engineering, Montana State University, Bozeman, Montana 59717, United States

*Lawrence Berkeley National Laboratory, Earth Sciences Division, Cyclotron Road, Berkeley, California 94720, United States

§South Dakota School of Mines and Technology, Chemical and Biological Engineering Department, Saint Joseph Street, Rapid City, South Dakota 57701, United States

ABSTRACT: Microbially mediated reduction of soluble U(VI) to U(IV) with subsequent precipitation of uraninite, $\mathrm{UO}_{2}(\mathrm{~S})$, has been proposed as a method for limiting uranium (U) migration. However, microbially reduced $\mathrm{UO}_{2}$ may be susceptible to reoxidation by environmental factors, with $\mathrm{Fe}(\mathrm{III})$ (hydr)oxides playing a significant role. Little is known about the role that organic compounds such as $\mathrm{Fe}(\mathrm{III})$ chelators play in the stability of reduced U. Here, we investigate the impact of citrate, DFB, EDTA, and NTA on biogenic $\mathrm{UO}_{2}$ reoxidation with ferrihydrite, goethite, and hematite. Experiments were conducted in anaerobic batch systems in PIPES buffer $(10 \mathrm{mM}, \mathrm{pH} 7)$ with bicarbonate for approximately 80 days. Results showed EDTA accelerated $\mathrm{UO}_{2}$ reoxidation the most at an initial rate of $9.5 \mu \mathrm{M}$ day ${ }^{-1}$ with ferrihydrite, $8.6 \mu \mathrm{M}$ day ${ }^{-1}$ with goethite, and $8.8 \mu \mathrm{M} \mathrm{day}^{-1}$ with hematite. NTA accelerated $\mathrm{UO}_{2}$ reoxidation with ferrihydrite at a rate of $4.8 \mu \mathrm{M}$ day $^{-1}$; rates were less with goethite and hematite $\left(0.66\right.$ and $0.71 \mu \mathrm{M} \mathrm{day}^{-1}$, respectively). Citrate increased $\mathrm{UO}_{2}$ reoxidation with ferrihydrite at a rate of $1.8 \mu \mathrm{M} \mathrm{day}^{-1}$, but did not increase the extent of reaction with goethite or hematite, with no reoxidation in this case. In all cases, bicarbonate increased the rate and extent of $\mathrm{UO} 2$ reoxidation with ferrihydrite in the presence and absence of chelators. The highest rate of UO2 reoxidation occurred when the chelator promoted both $\mathrm{UO} 2$ and $\mathrm{Fe}(\mathrm{III})$ (hydr)oxide dissolution as demonstrated with EDTA. When $\mathrm{UO} 2$ dissolution did not occur, $\mathrm{UO} 2$ reoxidation likely proceeded through an aqueous $\mathrm{Fe}(\mathrm{III})$ intermediate with lower reoxidation rates observed. Reaction modeling suggests that strong $\mathrm{Fe}(\mathrm{II})$ chelators promote reoxidation whereas strong $\mathrm{Fe}(\mathrm{III})$ chelators impede it. These results indicate that chelators found in $\mathrm{U}$ contaminated sites may play a significant role in mobilizing $U$, potentially affecting bioremediation efforts.

By the end of the cold war, uranium (U) contamination in the U.S. was present at one hundred and twenty nuclear weapon production sites covering $7280 \mathrm{~km}^{2}{ }^{1}$ At these sites, $\mathrm{U}$ is the most common radionuclide, ${ }^{2}$ making it a primary target for remediation by the Department of Energy (DOE). Under-standing the stability and mobility of Ubearing compounds is critical to the DOE remediation effort. In general, $\mathrm{U}(\mathrm{VI})$ compounds are considered more soluble, and thus more mobile, than $\mathrm{U}(\mathrm{IV})$ compounds, such that the oxidation of $\mathrm{U}(\mathrm{IV})$ to $\mathrm{U}(\mathrm{VI})$ is regarded as mobilizing $\mathrm{U}$. Conversely, reduction of $\mathrm{U}(\mathrm{VI})$ to $\mathrm{U}(\mathrm{IV})$ is considered to decrease the mobility of $U$ through the formation and precipitation of $\mathrm{U}(\mathrm{IV})$ minerals primarily as $\mathrm{UO}_{2} \cdot{ }^{3,4}$

In oxygen rich environments, $\mathrm{U}(\mathrm{VI})$ dominates and is primarily present as uranyl $\left(\mathrm{UO}_{2}{ }^{2+}\right)$ species, including uranyl complexes with hydroxide, phosphate, calcium, carbonate, and solid surfaces. In sufficiently reduced environments, $\mathrm{U}(\mathrm{IV})$ may remain stable ${ }^{5,6}$ and often resides as the relatively insoluble mineral $\mathrm{UO}_{2}(\mathrm{~s})$, uraninite. Redox reactions and complexation to organic and inorganic compounds often control U mobility and ultimate fate in surface and subsurface systems. While certain bacteria are known to reduce $\mathrm{U}(\mathrm{VI})$ to $\mathrm{U}(\mathrm{IV}),{ }^{7-12}$ microbial respiration increases bicarbonate concentrations that form strong complexes with U(VI), favoring mobilization. ${ }^{13-15}$ In microbial $U$ reduction remediation scenarios, it is important to characterize microbial and environmental factors that dictate $U$ oxidation state to ultimately understand and control the environmental fate and transport of U.

To ensure effective immobilization, reduced $\mathrm{U}$ must remain stable and resist reoxidation to its soluble and more mobile form. ${ }^{1}$ Numerous studies have shown biogenic $\mathrm{UO}_{2}$ reoxidation is affected by a variety of environmental factors. ${ }^{12,16-25}$ Previous studies have demonstrated $\mathrm{Fe}(\mathrm{III})$ (hydr)oxides can play a significant role in biogenic $\mathrm{UO}_{2}$ reoxidation, ${ }^{13,18,19,26,27,36}$ with the $\mathrm{Fe}(\mathrm{III})$ and $\mathrm{U}(\mathrm{IV})$ electron transfer mechanism shown in eq 1 : 


$$
\mathrm{U}(\mathrm{IV})+2 \mathrm{Fe}(\mathrm{III}) \leftrightarrow \mathrm{U}(\mathrm{VI})+2 \mathrm{Fe}(\mathrm{II})
$$

Biogenic $\mathrm{UO}_{2}$ reoxidation in the presence of $\mathrm{Fe}(\mathrm{III})$ (hydr)oxides has also been shown to proceed even under sulfate-reducing and methanogenic conditions. ${ }^{13,18,19,27}$ Thermodynamically, oxidation of biogenic $\mathrm{UO}_{2}$ in the presence of $\mathrm{Fe}$ (III) (hydr)oxides is favorable only under specific and limited geochemical conditions. For example, ferrihydrite is predicted to promote $\mathrm{UO}_{2}$ oxidation with elevated bicarbonate levels and low concentrations of $\mathrm{Fe}(\mathrm{II})$ and $\mathrm{U}(\mathrm{VI})$, while goethite and hematite generally are not expected to promote $\mathrm{UO}_{2}$ oxidation. $^{21,25}$

In addition, iron-binding organic compounds have been shown to impact $\mathrm{U}$ transformations. Chelating compounds including citrate, ethylenediaminetetraacetic acid (EDTA), and nitrilotriacetic acid (NTA) were demonstrated to inhibit bacterial production of $\mathrm{UO}_{2}$ through formation of soluble $\mathrm{U}(\mathrm{IV})$-organic complexes upon reduction of $\mathrm{U}(\mathrm{VI})$ by Shewanella putrefaciens. ${ }^{14,28,29}$ Additionally, chelating agents were found to impact reduction and oxidation kinetics of uranium and in some cases influence dissolution of U-bearing minerals. ${ }^{30-32}$ These chelators are present in certain U contaminated settings due to their use as complexing agents in radioactive waste streams, ${ }^{33,34}$ yet the complete nature of their role in $U$ stability remains unclear.

This study examines the effects of Fe(III) (hydr)oxides (ferrihydrite, goethite, and hematite) on reoxidation of biogenically reduced $U$ in the presence of desferrioxamine $B$ (DFB), citrate, NTA, and EDTA. The Fe(III) (hydr)oxides studied vary in reactivity ${ }^{35}$ and thus drive the reoxidation of $\mathrm{UO}_{2}$ to different degrees. ${ }^{21,36}$ In addition, the role of bicarbonate on $\mathrm{U}-\mathrm{Fe}(\mathrm{III})$-chelator systems was investigated both experimentally and through numerical modeling, due to previous reports of its influence on the reoxidation of $\mathrm{UO}_{2}$ by $\mathrm{Fe}(\mathrm{III}) .{ }^{13}$ Results presented here provide significant additional insight into $U(I V)$ stability and the potential role of metal chelating agents in long-term $\mathrm{U}$ immobilization efforts.

\section{MATERIALS AND METHODS}

Biogenic Uraninite. All experiments were performed in an anaerobic chamber (Coy Laboratory Products Inc.) containing a premixed gas of $90 \% \mathrm{~N}_{2}, 5 \% \mathrm{H}_{2}$, and $5 \% \mathrm{CO}_{2}$ (by volume). Biogenic $\mathrm{UO}_{2}$ was synthesized using a slightly modified version of Ulrich et al. ${ }^{22}$ through the reduction of uranyl chloride $\left(\mathrm{UO}_{2} \mathrm{Cl}_{2}\right)$ by Shewanella putrefaciens $\mathrm{CN} 32$ coupled to lactate oxidation at $\mathrm{pH}$ 7. Medium components consisted of the following per $1 \mathrm{~L}$ : $30 \mathrm{mmol} \mathrm{KHCO}_{3}, 1.5 \mu \mathrm{L}$ Wolfe's minerals, ${ }^{37}$ $10 \mathrm{mmol} \mathrm{PIPES}, 0.067 \mathrm{mmol} \mathrm{KCl}, 0.42 \mathrm{mmol} \mathrm{MgSO}_{4}, 0.5$ $\mathrm{mmol} \mathrm{NaCl}, 18.7 \mathrm{mmol} \mathrm{NH}_{4} \mathrm{Cl}, 7.35 \mathrm{mmol} \mathrm{KH}_{2} \mathrm{PO}_{4}$, and 30 mmol sodium lactate. Uraninite was produced by adding CN32 cells and $1.375 \mathrm{~g} \mathrm{UO}_{2} \mathrm{Cl}_{2}$ to $1 \mathrm{~L}$ of medium in an anaerobic chamber. After $5 \mathrm{~d}, 10 \mathrm{mmol}$ additional sodium lactate was added to enhance reduction. Following reduction for $12 \mathrm{~d}$, the uraninite product was purified and washed following the method described by Ulrich et al. ${ }^{22}$ Briefly, the solution was centrifuged and then treated with $1 \mathrm{M} \mathrm{NaOH}$ to destroy intact cells, followed by incubation with anoxic hexane to separate any remaining organic matter. Lastly, reduced $U$ was resuspended in $100 \mathrm{mM}$ anoxic $\mathrm{KHCO}_{3}$ to remove any remaining $\mathrm{U}(\mathrm{VI})$ adsorbed on the $\mathrm{UO}_{2}$ particles and stored in the anaerobic chamber until needed. The $U$ concentration was measured by oxidizing unfiltered samples with concentrated $\mathrm{HNO}_{3}$ over- night and analyzing on a kinetic phosphorescence analyzer (Chemchek Instruments, KPA-11).

Fe(III) (Hydr)oxide Preparation. Ferrihydrite was synthesized as described by Brooks et al. ${ }^{38}$ Briefly, the $\mathrm{pH}$ of a $0.06 \mathrm{M}$ ferric chloride solution was adjusted to 7.5 with $0.4 \mathrm{~N} \mathrm{NaOH}$ over a period of several hours. Goethite was prepared as described by Atkinson et al., ${ }^{39}$ where $1 \mathrm{M} \mathrm{NaOH}$ was added to a ferric nitrate solution while being continuously stirred over 3 to $4 \mathrm{~h}$ until a $\mathrm{pH}$ of 12 was reached. This iron slurry was placed in a $60{ }^{\circ} \mathrm{C}$ oven for $24 \mathrm{~h}$, and the salts were removed by dialysis over a period of approximately two weeks. Hematite was synthesized as described by Schwertmann and Cornell, ${ }^{40}$ where $1 \mathrm{M}$ ferric nitrate was slowly added to boiling distilled water over a period of $4 \mathrm{~h}$. The salts were removed by dialysis for approximately two weeks. The goethite and hematite slurry were stored at $4{ }^{\circ} \mathrm{C}$.

Each $\mathrm{Fe}$ (III) (hydr)oxide sample was prepared individually. Each iron slurry was then poured onto quartz sand (Iota 6 Quartz Sand, Unimin Corp., 75-300 $\mu \mathrm{m}$ ) in separate plastic trays and mixed by hand as described by Brooks et al. ${ }^{38}$ The sands dried for at least $48 \mathrm{~h}$, after which they were rinsed with nanopure water. Rinsing was repeated until the water being decanted was clear. After rinsing, the iron-coated sands were allowed to dry for at least $12 \mathrm{~h}$. Hematite and goethite were stored at room temperature until needed, while ferrihydrite was stored at room temperature and used within 2 weeks of preparation.

$\mathrm{Fe}(\mathrm{III})$ concentrations on the sand were measured by adding concentrated $\mathrm{HNO}_{3}$ to the iron-coated sand to allow $\mathrm{Fe}$ (III) to dissociate from the quartz. Aqueous Fe concentrations were measured on an inductively coupled plasma mass spectrometer (ICP-MS, Agilent). Iron(III) concentrations were approximately $6 \pm 0.7 \mathrm{~g}$ of $\mathrm{Fe}(\mathrm{III})$ per $\mathrm{mg}$ of sand.

Aqueous $\mathrm{U}(\mathrm{VI})$ and Total Aqueous $\mathrm{U}$. To measure aqueous $\mathrm{U}(\mathrm{VI})$ concentrations, samples were extracted from bottles by syringe in the anoxic chamber and filtered $(0.2 \mu \mathrm{m}$, Fisher). The filtered sample was placed in a scintillation vial and the lid was tightly fastened to prevent air entering the vial. Samples were taken out of the glovebag in groups of approximately seven to ensure no $\mathrm{UO}_{2}$ oxidation occurred due to atmospheric oxygen (small groups of samples decreased the amount of time outside of the glovebag prior to analysis). The samples were mixed with $0.1 \mathrm{M} \mathrm{H}_{2} \mathrm{SO}_{4}$ and then added to dilute uraplex (Chemcheck Instruments). $\mathrm{H}_{2} \mathrm{SO}_{4}$ was used for $\mathrm{U}(\mathrm{VI})$ analysis instead of $\mathrm{HNO}_{3}$ to avoid possible oxidation by nitrate. To minimize exposure time, samples were placed manually in the KPA-11 (Chemcheck Instruments). Calibration curves for the KPA-11 were made with a $U$ standard solution in $5 \%$ nitric acid ( $1000 \mathrm{ppm} \pm 10 \mu \mathrm{g} \mathrm{mL}^{-1}$, GFS Chemicals, Inc.) diluted in $0.1 \mathrm{M} \mathrm{H}_{2} \mathrm{SO}_{4}$ ranging from concentration values of 0 $\mu \mathrm{M}$ to $150 \mu \mathrm{M}$. All samples and standards were diluted by a factor of 200. Negative KPA-11 responses were regarded as zero. With these conditions, the $\mathrm{U}(\mathrm{VI})$ detection limit was 0.2 $\mu \mathrm{M}$.

To measure total aqueous $\mathrm{U}$ concentrations (U(VI)aq + $\mathrm{U}(\mathrm{IV}) \mathrm{aq})$, samples were filtered $(0.2 \mu \mathrm{m})$ and placed in a 3 KDa Nanosep centrifugal device (Pall Life Sciences) in a glovebag and centrifuged (14565 g) on the benchtop for 15 min to eliminate any solid $U$ that passed through the $0.2 \mu \mathrm{m}$ filters under anoxic conditions. The filtered sample was then added to concentrated $\mathrm{HNO}_{3}$ and incubated for at least $1 \mathrm{~h}$ to allow any aqueous $\mathrm{U}(\mathrm{IV})$ to oxidize to $\mathrm{U}(\mathrm{VI})$. The samples were then measured on the KPA-11. The total aqueous $U$ was 
measured, and aqueous U(IV) concentrations were calculated by difference. A separate calibration curve was used for total $\mathrm{U}$ measurements with the $\mathrm{U}$ standard diluted in $0.1 \mathrm{M} \mathrm{HNO}_{3}$ at concentrations ranging from $0 \mu \mathrm{M}$ to $150 \mu \mathrm{M}$. Negative KPA11 responses were regarded as zero and detection limit was 0.2 $\mu \mathrm{M}$ (lowest consistent measurable concentration). In reoxidation experiments, the difference between dissolution without oxidation and actual oxidation was determined by measuring $\mathrm{U}(\mathrm{VI})$ and $\mathrm{U}($ total) $(\mathrm{U}(\mathrm{VI})+\mathrm{U}(\mathrm{IV})$ ) and calculating $\mathrm{U}(\mathrm{IV})$ by the difference. The presence of U(VI) indicated oxidation.

Total Dissolved Iron. Soluble iron concentrations were measured by ICP-MS. Samples were diluted in a $5 \%$ trace metal grade $\mathrm{HNO}_{3}$ (Fisher Scientific) and stored at $4{ }^{\circ} \mathrm{C}$ until analysis. Iron standards in $5 \% \mathrm{HNO}_{3}$ were made using an iron reference standard solution $(1000 \mathrm{ppm} \pm 1)$ at concentrations ranging from $0 \mu \mathrm{M}$ to $895 \mu \mathrm{M}$ with a calculated detection limit for iron of $0.179 \mu \mathrm{M}$. Iron(II) measurements using ferrozine were attempted but did not yield any measurable amounts.

$\mathrm{UO}_{2}$ Dissolution Experiments. Uraninite dissolution experiments investigated the effects of various chelators on dissolution rates of $\mathrm{UO}_{2}$. Uranium and chelator concentrations were selected based on midrange values found in some contaminated settings. Serum bottles $(50 \mathrm{~mL})$ initially contained biogenic $\mathrm{UO}_{2}(125 \mu \mathrm{M}), 50 \mathrm{~mL}$ of $10 \mathrm{mM}$ PIPES buffer at $\mathrm{pH} 7$ with $0.0,0.1$, or $0.2 \mathrm{mM}$ chelator (DFB, citrate, EDTA, or NTA). All media and experimental constituents were purged with $\mathrm{N}_{2}$ gas until no oxygen remained (approximately 2 h, confirmed by measurement with dissolved oxygen probe). Potassium bicarbonate was added to a final concentration of 10 $\mathrm{mM}$ following $\mathrm{N}_{2}$ purging. Conditions throughout experiments and sampling were maintained as reducing and oxygen-free as possible. Systems with no chelator were used as controls for these experiments. Samples were filtered $(0.2 \mu \mathrm{m})$ and analyzed for $U(V I)$. Then, the filtered sample was measured for total dissolved $U$ to calculate aqueous $U(I V)$ concentrations by subtraction (as described above). Separate experiments were conducted in triplicate for each chelator (DFB, citrate, EDTA, and NTA). Error bars represent standard deviation among triplicates. A second set of dissolution experiments investigated the effects of various chelators on solubilization of Fe(III) (hydr)oxides (details are provided in the Supporting Information).

$\mathrm{UO}_{2}$ Reoxidation Experiments. To investigate the effects of chelating agents on $\mathrm{UO}_{2}$ reoxidation in the presence of $\mathrm{Fe}$ (III) (hydr)oxides, batch experiments were conducted in the same way as the $\mathrm{UO}_{2}$ dissolution experiments with the addition of $1 \mathrm{~g}$ iron-coated sands (approximately $2.5 \mathrm{mM}$ of $\mathrm{Fe}$ (III) in each serum bottle). Samples were filtered $(0.2 \mu \mathrm{m})$ and analyzed for U(VI) concentrations using the KPA-11 over $80 \mathrm{~d}$. Separate experiments were run with each of the three Fe(III) (hydr)oxides (ferrihydrite, goethite, and hematite) and each chelator (DFB, citrate, EDTA, and NTA). Additional experiments were conducted with each of the chelating agents and $\mathrm{Fe}$ (III) chloride to compare the oxidizing behavior of an aqueous form of $\mathrm{Fe}$ (III) to that of the $\mathrm{Fe}(\mathrm{III})$ (hydr)oxides.

\section{RESULTS AND DISCUSSION}

Dissolution Experiments. In these experiments, increased $\mathrm{U}(\mathrm{VI})$ concentrations may result from reoxidation of $\mathrm{UO}_{2}$ or extraction of $\mathrm{U}(\mathrm{VI})$ from $\mathrm{UO}_{2}$ surfaces. Approximately $4 \%$ of $\mathrm{U}$ in the biogenic $\mathrm{UO}_{2}$ remained as $\mathrm{U}(\mathrm{VI})$ in this study (determined through nitric acid digestion followed by total $\mathrm{U}$ and $\mathrm{U}(\mathrm{VI})$ measurement as described in the methods section), consistent with the findings of Ginder-Vogel et al. ${ }^{21}$ In chelatorfree control systems, total dissolved $U$ concentrations were below $1 \mu \mathrm{M}$, with virtually no difference between $\mathrm{U}(\mathrm{VI})$ and total dissolved U concentrations. Systems with citrate yielded similar results suggesting that citrate did not promote significant $\mathrm{UO}_{2}$ dissolution nor was it able to appreciably extract adsorbed $\mathrm{U}(\mathrm{VI})$. As in the case of experiments with citrate, $\mathrm{U}(\mathrm{VI})$ and total dissolved $\mathrm{U}$ concentrations in systems with NTA were the same with a maximum value of approximately $3 \mu \mathrm{M}$, suggesting that NTA also did not promote significant $\mathrm{U}(\mathrm{IV})$ dissolution. However, comparing chelator-free $\mathrm{U}(\mathrm{VI})$ concentrations to systems with NTA shows that NTA slightly increased aqueous U(VI) concentrations. These results suggest that NTA increased the amount of aqueous $\mathrm{U}(\mathrm{VI})$ primarily through extraction of $\mathrm{U}(\mathrm{VI})$ adsorbed to $\mathrm{UO}_{2}$ particles and not through dissolution of $\mathrm{U}(\mathrm{IV})$ in the $\mathrm{UO}_{2}$ mineral structure. Figure 1 shows that, in systems with

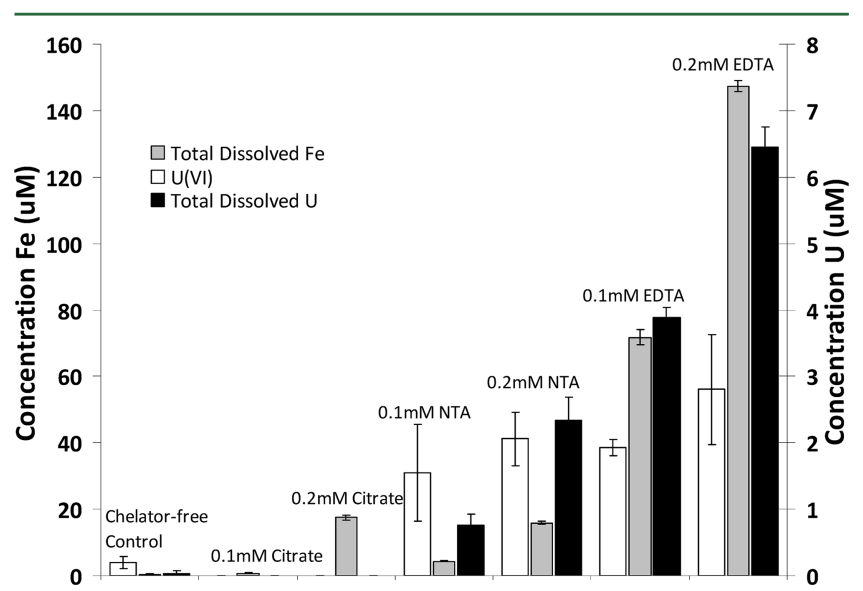

Figure 1. Dissolution of biogenic $\mathrm{UO}_{2}$ (black) and ferrihydrite (gray) by citrate, NTA, or EDTA in $10 \mathrm{mM}$ bicarbonate solutions after approximately 80 days showing that both NTA and EDTA promote $\mathrm{UO}_{2}$ and ferrihydrite dissolution, while citrate promotes ferrihydrite dissolution but not $\mathrm{UO}_{2}$ dissolution. The extent of dissolution was significantly less with NTA compared to EDTA. Error bars represent the standard deviation of triplicates.

EDTA, U(VI) and total $U$ concentrations increased with increasing concentrations of EDTA. With EDTA, because total dissolved $\mathrm{U}$ concentrations were greater $(\sim 6 \mu \mathrm{M}$ after $80 \mathrm{~d})$ than $\mathrm{U}(\mathrm{VI})$ concentrations $(\sim 3 \mu \mathrm{M}$ after $80 \mathrm{~d})$, it appears that EDTA promoted $\mathrm{UO}_{2}$ dissolution as U(IV) and also increased aqueous $\mathrm{U}(\mathrm{VI})$ concentrations. The addition of either NTA or EDTA promoted some dissolution of $\mathrm{U}(\mathrm{IV})$ in the $\mathrm{UO}_{2}$ mineral with initial rates of $5.5 \times 10^{-2} \mu \mathrm{M} \mathrm{U} \mathrm{d}^{-1}$ and $2.8 \times$ $10^{-1} \mu \mathrm{M} \mathrm{U} \mathrm{d}^{-1}$ for $0.2 \mathrm{mM}$ NTA and EDTA respectively (Table 1).

When comparing the chelator-promoted dissolution of $\mathrm{Fe}(\mathrm{III})$ (hydr) oxides and $\mathrm{UO}_{2}$ in dissolution experiments, the amount of soluble Fe was much greater than soluble $U$ in all cases. In systems with $0.2 \mathrm{mM}$ EDTA, total soluble Fe concentrations were approximately $150 \mu \mathrm{M}$ compared to total soluble $\mathrm{U}$ concentrations of approximately $6 \mu \mathrm{M}$ (Figure 1 ). When compared to the chelator-free control, EDTA and NTA increased both total dissolved Fe and $\mathrm{U}$.

$\mathrm{UO}_{2}$ Reoxidation Experiments. The ability of ferrihydrite, goethite, and hematite to reoxidize biogenic $\mathrm{UO}_{2}$ in the presence of citrate, NTA, or EDTA was investigated. In chelator-free control experiments, $\mathrm{UO}_{2}$ reoxidation by ferrihy- 
Table 1. Average Initial Rates for $\mathrm{UO}_{2}$ Dissolution Experiments with EDTA and NTA $(0,0.1$, or $0.2 \mathrm{mM})$ with $10 \mathrm{mM}$ Bicarbonate

\begin{tabular}{ll} 
& avg initial rate $\left(\mu \mathrm{M}\right.$ total $\left.\mathrm{U} \mathrm{d}^{-1}\right)$ \\
\hline 0 chelator & $0.0 \times 10^{00}$ \\
0.1 citrate & $0.0 \times 10^{00}$ \\
0.2 citrate & $0.0 \times 10^{00}$ \\
0.1 NTA & $7.3 \times 10^{-02}$ \\
0.2 NTA & $5.5 \times 10^{-02}$ \\
0.1 EDTA & $1.6 \times 10^{-01}$ \\
0.2 EDTA & $2.8 \times 10^{-01}$
\end{tabular}

drite was observed with approximately $15 \mu \mathrm{M}$ of $\mathrm{U}(\mathrm{VI})$ detected after $80 \mathrm{~d}$, consistent with the results of Ginder-Vogel et al., ${ }^{21}$ who proposed a mechanism that involves ferrihydrite solubilizing and promoting $\mathrm{UO}_{2}$ reoxidation through an aqueous $\mathrm{Fe}$ (III) intermediate. ${ }^{25}$

Figure 2 shows the initial rate of $\mathrm{UO}_{2}$ reoxidation by ferrihydrite in the presence of citrate was 0.88 and $1.8 \mu \mathrm{M}$

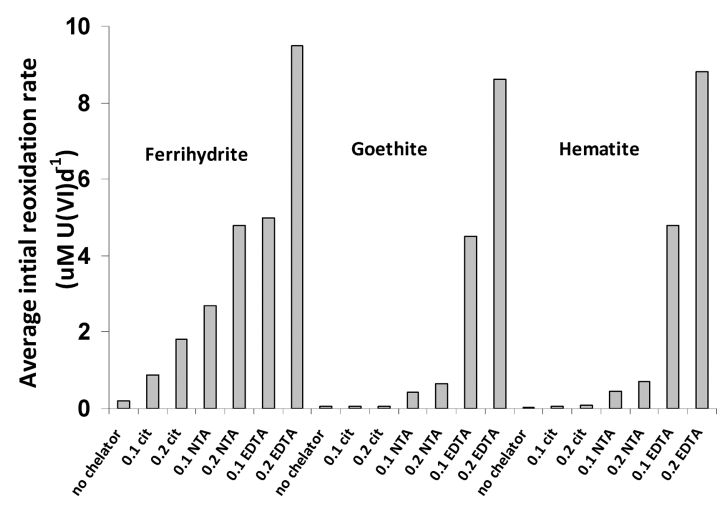

Figure 2. Average initial rates for $\mathrm{UO}_{2}$ reoxidation by ferrihydrite, goethite, or hematite in the presence of no chelator, citrate (cit), EDTA, or NTA (0.1 or $0.2 \mathrm{mM}), 10 \mathrm{mM}$ bicarbonate, and PIPES ( $\mathrm{pH}$ $=7)$.

$\mathrm{U}(\mathrm{VI}) \mathrm{d}^{-1}$ in systems containing 0.1 and $0.2 \mathrm{mM}$ citrate respectively. Figure 3 expands upon citrate results and shows that citrate did not promote dissolution of $\mathrm{UO}_{2}$, suggesting that the reoxidation rate accelerating step is citrate promoting

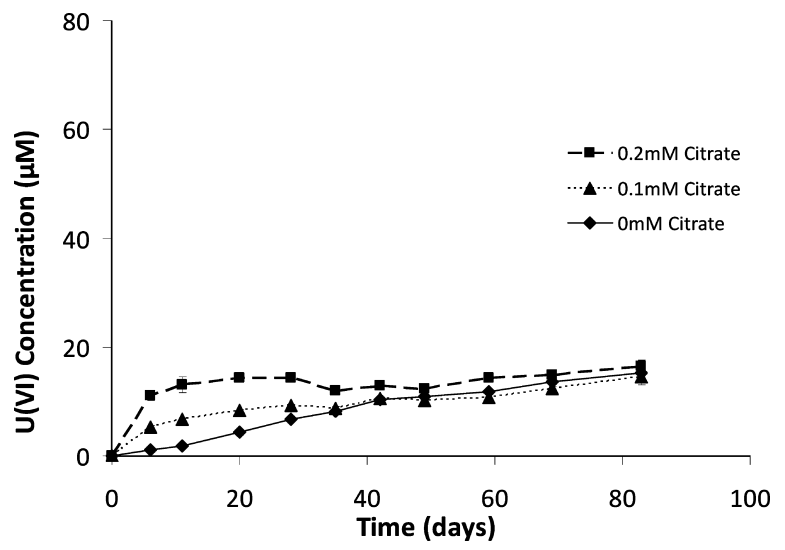

Figure 3. $\mathrm{UO}_{2}$ reoxidation in the presence of citrate and ferrihydrite with $10 \mathrm{mM}$ bicarbonate and PIPES $(\mathrm{pH}=7)$ showing that citrate increases the rate of $\mathrm{UO}_{2}$ reoxidation but not the extent. Error bars represent the standard deviation of triplicates. dissolution of ferrihydrite, which in turn allows soluble $\mathrm{Fe}$ (III) to react with $\mathrm{UO}_{2}$, thus promoting $\mathrm{U}$ reoxidation. Limited reoxidation was observed with goethite and hematite in the citrate-free control, and $\mathrm{U}$ concentrations remained below 2 $\mu \mathrm{M}$ with citrate (results not shown). In comparison to ferrihydrite, goethite and hematite are less reactive toward $\mathrm{U}$, likely due to their not being as easily solubilized by citrate, and did not play a significant role in citrate-mediated $\mathrm{UO}_{2}$ reoxidation.

$\mathrm{UO}_{2}$ reoxidation in the presence of NTA was more appreciable than with citrate (Figure 4 and 5). NTA solubilized

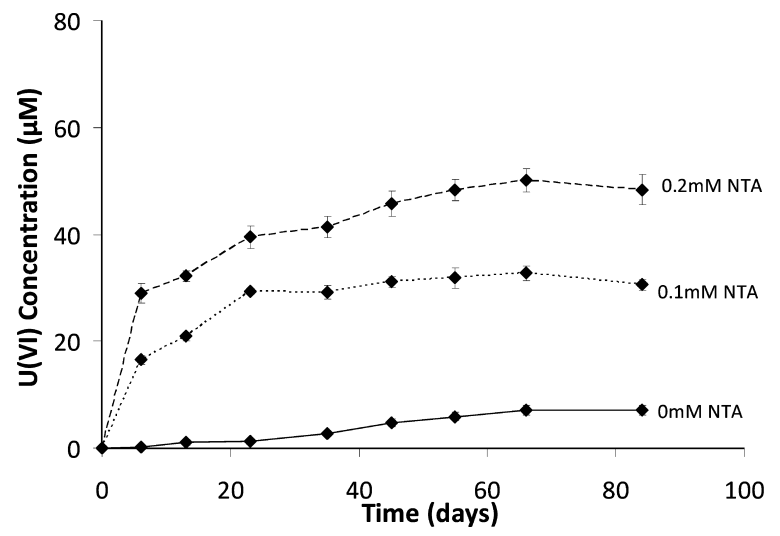

Figure 4. $\mathrm{UO}_{2}$ reoxidation in the presence of NTA and ferrihydrite with $10 \mathrm{mM}$ bicarbonate and PIPES $(\mathrm{pH}=7)$ showing that NTA increases the rate of $\mathrm{UO}_{2}$ reoxidation. Error bars represent the standard deviation of triplicates.

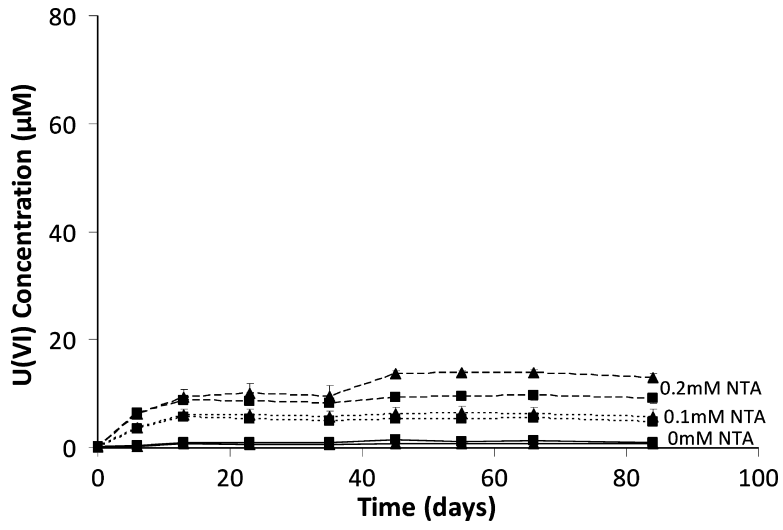

Figure 5. $\mathrm{UO}_{2}$ reoxidation in the presence of NTA and hematite $(\boldsymbol{\Delta})$ or goethite ( $)$ with $10 \mathrm{mM}$ bicarbonate and PIPES $(\mathrm{pH}=7)$ showing that NTA increases the rate of $\mathrm{UO}_{2}$ reoxidation. Error bars represent the standard deviation of triplicates.

ferrihydrite at an initial rate of $1.1 \mu \mathrm{M} \mathrm{Fe} \mathrm{d}^{-1}$ but did not solubilize goethite or hematite as efficiently with a maximum initial rate of only $0.029 \mu \mathrm{M} \mathrm{Fe} \mathrm{d} \mathrm{d}^{-1}$ (Table S1, Supporting Information). After $80 \mathrm{~d}$ with $0.2 \mathrm{mM}$ NTA and ferrihydrite, $\mathrm{U}(\mathrm{VI})$ concentrations were approximately $50 \mu \mathrm{M}$ with an initial reoxidation rate of $4.81 \mu \mathrm{M} \mathrm{U}(\mathrm{VI}) \mathrm{d}^{-1}$, while with either goethite or hematite $\mathrm{U}(\mathrm{VI})$ was below $20 \mu \mathrm{M}$. In all systems, increased NTA concentration resulted in greater U(VI) values. Heterogenous reaction modeling simulations suggest that this results from a stronger complexation of $\mathrm{Fe}$ (II) with NTA than with citrate, favoring reoxidation by lowering the activity of $\mathrm{Fe}^{2+}$ in solution (reaction 1), with the formation of $\mathrm{Fe}(\mathrm{III})$ chelates computed to be insignificant relative to the $\mathrm{Fe}(\mathrm{II})$ 
chelates. U(VI) concentrations were highest in systems with ferrihydrite, indicating that (similar to citrate) NTA-promoted reductive iron dissolution as an $\mathrm{Fe}$ (II) chelate appears to play a key role in determining the $\mathrm{U}$ reoxidation rate.

The rate and extent of $\mathrm{UO}_{2}$ reoxidation by $\mathrm{Fe}(\mathrm{III})$ minerals with EDTA was significantly higher than in systems with either NTA or citrate. During the first week of incubation with 0.2 $\mathrm{mM}$ EDTA, aqueous U(VI) concentrations rose to approximately $60 \mu \mathrm{M}$. Figure 2 shows initial reoxidation rates of 9.54 , 8.56, and 8.81 $\mu \mathrm{M} \mathrm{U}(\mathrm{VI}) \mathrm{d}^{-1}$ for ferrihydrite, goethite, and hematite, respectively. As initial rates with all three minerals were similar, reoxidation in the presence of EDTA appeared independent of the Fe(III) (hydr)oxide present. This could be explained by the complete dissolution of available solid Fe(III) with all three minerals, as suggested by modeling calculations, or by surface passivation of $\mathrm{Fe}(\mathrm{III})$ minerals and/or $\mathrm{UO}_{2}$ particles with $\mathrm{Fe}(\mathrm{II})$ and/or U(VI). The maximum observed concentration of soluble $\mathrm{U}(\mathrm{VI})$ was dependent on the concentration of EDTA present, with increased EDTA leading to greater $\mathrm{U}(\mathrm{VI})$ concentrations. As compared to citrate and NTA, Figure 2 shows EDTA reoxidized $\mathrm{UO}_{2}$ at a faster initial rate than citrate (initial rate $=1.82 \mu \mathrm{M} \mathrm{U}(\mathrm{VI}) \mathrm{d}^{-1}$ ) or NTA (initial rate $=4.81 \mu \mathrm{M} \mathrm{U}(\mathrm{VI}) \mathrm{d}^{-1}$ ).

When comparing the three Fe(III) (hydr)oxides in Figure 6, $\mathrm{U}(\mathrm{VI})$ concentrations were similar for a given EDTA

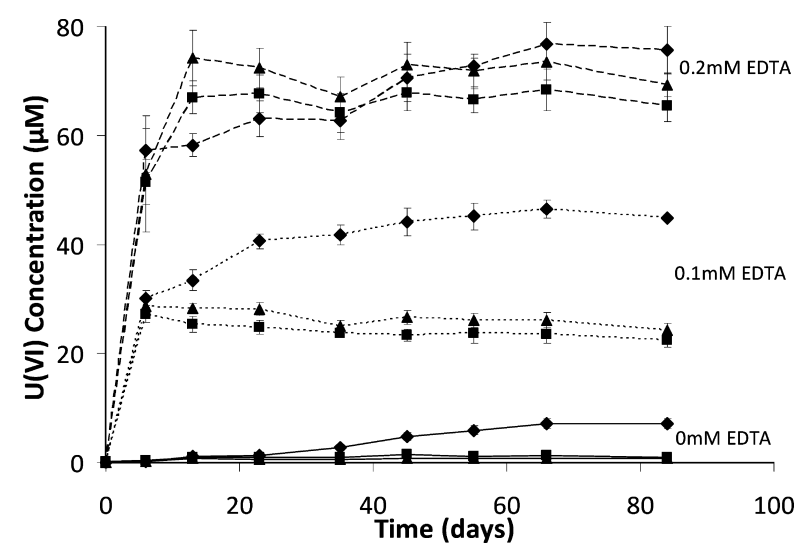

Figure 6. $\mathrm{UO}_{2}$ reoxidation in the presence of EDTA and ferrihydrite $(\boldsymbol{\nabla})$, hematite $(\boldsymbol{\Delta})$, or goethite $(\boldsymbol{\square})$, with $10 \mathrm{mM}$ bicarbonate and PIPES $(\mathrm{pH}=7)$ showing that EDTA increases the rate of $\mathrm{UO}_{2}$ reoxidation.

concentration, indicating that EDTA likely dissolved some $\mathrm{UO}_{2}$ in addition to solubilization of $\mathrm{Fe}$ (III) (hydr)oxides. These results support the findings of Ginder-Vogel et al. ${ }^{25}$ where the authors hypothesized that the rate controlling step in $\mathrm{UO}_{2}$ reoxidation by $\mathrm{Fe}(\mathrm{III})$ (hydr)oxides is interaction through a soluble U(IV) intermediate. Since EDTA increased dissolution rates of both $\mathrm{UO}_{2}$ and $\mathrm{Fe}$ (III) (hydr) oxides (Figure 1), $\mathrm{UO}_{2}$ reoxidation was more extensive than with citrate, where only iron was solubilized, or with NTA, where iron was solubilized and $\mathrm{U}(\mathrm{VI})$ extracted from $\mathrm{UO}_{2}$ particles.

Iron(III) (hydr)oxide minerals were also tested for their ability to reoxidize biogenic $\mathrm{UO}_{2}$ in the presence of the siderophore desferrioxamine B (DFB), with $10 \mathrm{mM}$ bicarbonate at $\mathrm{pH}$ 7. No reoxidation was observed in any system that contained DFB (results not shown) and Fe(III) (hydr)oxides. A possible explanation for this observation is the high thermodynamic stability of DFB-Fe(III) complexes, which could tie up $\mathrm{Fe}$ (III) such that it is essentially unreactive toward $\mathrm{UO}_{2}$. An additional experiment with aqueous $\mathrm{Fe}(\mathrm{III})$ and $\mathrm{DFB}$ showed no reoxidation with $1: 1 \mathrm{Fe}(\mathrm{III})_{(\mathrm{aq})} / \mathrm{DFB}$ and $\sim 25 \%$ reoxidation with $2: 1 \mathrm{Fe}(\mathrm{III})_{(\mathrm{aq})} / \mathrm{DFB}$. Note that the other chelators in this study bind less strongly with $\mathrm{Fe}$ (III) compared to DFB, which allows more uncomplexed $\mathrm{Fe}$ (III) to be available to interact with $\mathrm{UO}_{2}$ in systems with these chelators.

Of the chelators tested in this study, EDTA promoted the greatest amount of $\mathrm{UO}_{2}$ reoxidation, followed by NTA. EDTA solubilized all three $\mathrm{Fe}$ (III) (hydr)oxides as well as biogenic $\mathrm{UO}_{2}$, allowing for over half the total $\mathrm{U}$ present (approximately $4 \mu \mathrm{mol}$ ) to be reoxidized within the first week of incubation. Reaction modeling results presented below suggest that the observed progressively stronger $\mathrm{UO}_{2}$ reoxidation with citrate, NTA, and EDTA at $\mathrm{pH} 7$ results from the formation of progressively stronger complexes of these chelators with $\mathrm{Fe}(\mathrm{II})$, and not with U(VI). This could allow for either aqueous $\mathrm{Fe}(\mathrm{III})$ or an $\mathrm{Fe}$ (III)-EDTA complex to react with the solid uraninite, aqueous U(IV), and/or an U(IV)-EDTA complex. Conversely, citrate and NTA appear more limited in interacting with the $\mathrm{Fe}$ (III) minerals (ferrihydrite in most cases), promoting $\mathrm{U}$ reoxidation through formation of $\mathrm{Fe}(\mathrm{II})$ chelates, and either aqueous $\mathrm{Fe}(\mathrm{III})$ or an $\mathrm{Fe}(\mathrm{III})$-chelator complex interacting with solid $\mathrm{UO}_{2}$. Additional reoxidation experiments were conducted with $\mathrm{Fe}$ (III) chloride and each of the chelating agents to compare the reoxidation trends of a soluble $\mathrm{Fe}(\mathrm{III})$ source to those of the Fe(III) (hydr)oxides. Results followed a similar trend as with the $\mathrm{Fe}$ (III) (hydr)oxides, where greater rate and extent of reoxidation were observed in the presence of EDTA and NTA compared to citrate and DFB (Figure S2, Supporting Information).

Numerical Modeling. Multicomponent heterogeneous reaction modeling simulations were performed to investigate the oxidation of $\mathrm{UO}_{2}$ by hematite in systems containing citrate, NTA, and EDTA at equilibrium under a range of $\mathrm{pH}$ conditions (Figure 7). These simulations indicate that the increased $\mathrm{UO}_{2}$ reoxidation near $\mathrm{pH} 7$ in the presence of chelators, $10 \mathrm{mM}$ bicarbonate, and hematite results from the formation of strong $\mathrm{Fe}(\mathrm{II})$-chelator and $\mathrm{U}(\mathrm{VI})$ carbonate complexes, rather than from $\mathrm{U}(\mathrm{VI})$-chelator species, following the reactions:

$$
\begin{aligned}
& \mathrm{UO}_{2}(\mathrm{cr})+\mathrm{Fe}_{2} \mathrm{O}_{3}(\mathrm{cr})+3 \mathrm{HCO}_{3}^{-}+3 \mathrm{H}^{+}+2 \mathrm{Citrate}^{-3} \\
& \rightarrow \mathrm{UO}_{2}\left(\mathrm{CO}_{3}\right)_{3}^{-4}+2 \mathrm{Fe}(\mathrm{II}) \mathrm{Citrate}^{-}+3 \mathrm{H}_{2} \mathrm{O} \\
& \log _{10}(\mathrm{~K})=15.25 \\
& \mathrm{UO}_{2}(\mathrm{cr})+\mathrm{Fe}_{2} \mathrm{O}_{3}(\mathrm{cr})+3 \mathrm{HCO}_{3}^{-}+3 \mathrm{H}^{+}+2 \mathrm{NTA}^{-3} \\
& \rightarrow \mathrm{UO}_{2}\left(\mathrm{CO}_{3}\right)_{3}^{-4}+2 \mathrm{Fe}(\mathrm{II}) \mathrm{NTA}^{-}+3 \mathrm{H}_{2} \mathrm{O} \\
& \log _{10}(\mathrm{~K})=23.43 \\
& \mathrm{UO}_{2}(\mathrm{cr})+\mathrm{Fe}_{2} \mathrm{O}_{3}(\mathrm{cr})+3 \mathrm{HCO}{ }^{-}+3 \mathrm{H}^{+}+2 \mathrm{EDTA}^{-4} \\
& \rightarrow \mathrm{UO}_{2}\left(\mathrm{CO}_{3}\right)_{3}^{-4}+2 \mathrm{Fe}(\mathrm{II}) \mathrm{EDTA}^{-2}+3 \mathrm{H}_{2} \mathrm{O} \\
& \log _{10}(\mathrm{~K})=35.05
\end{aligned}
$$

The progressively increasing $\log _{10}(K)$ values of these reactions $\left(\Delta G=-2.3 R T \log _{10}(K)\right)$ imply that on the basis of thermodynamics alone, $\mathrm{UO}_{2}$ reoxidation at $\mathrm{pH} \sim 7$ should be progressively higher in the citrate, NTA, and EDTA systems, respectively, which is consistent with experimental observa- 

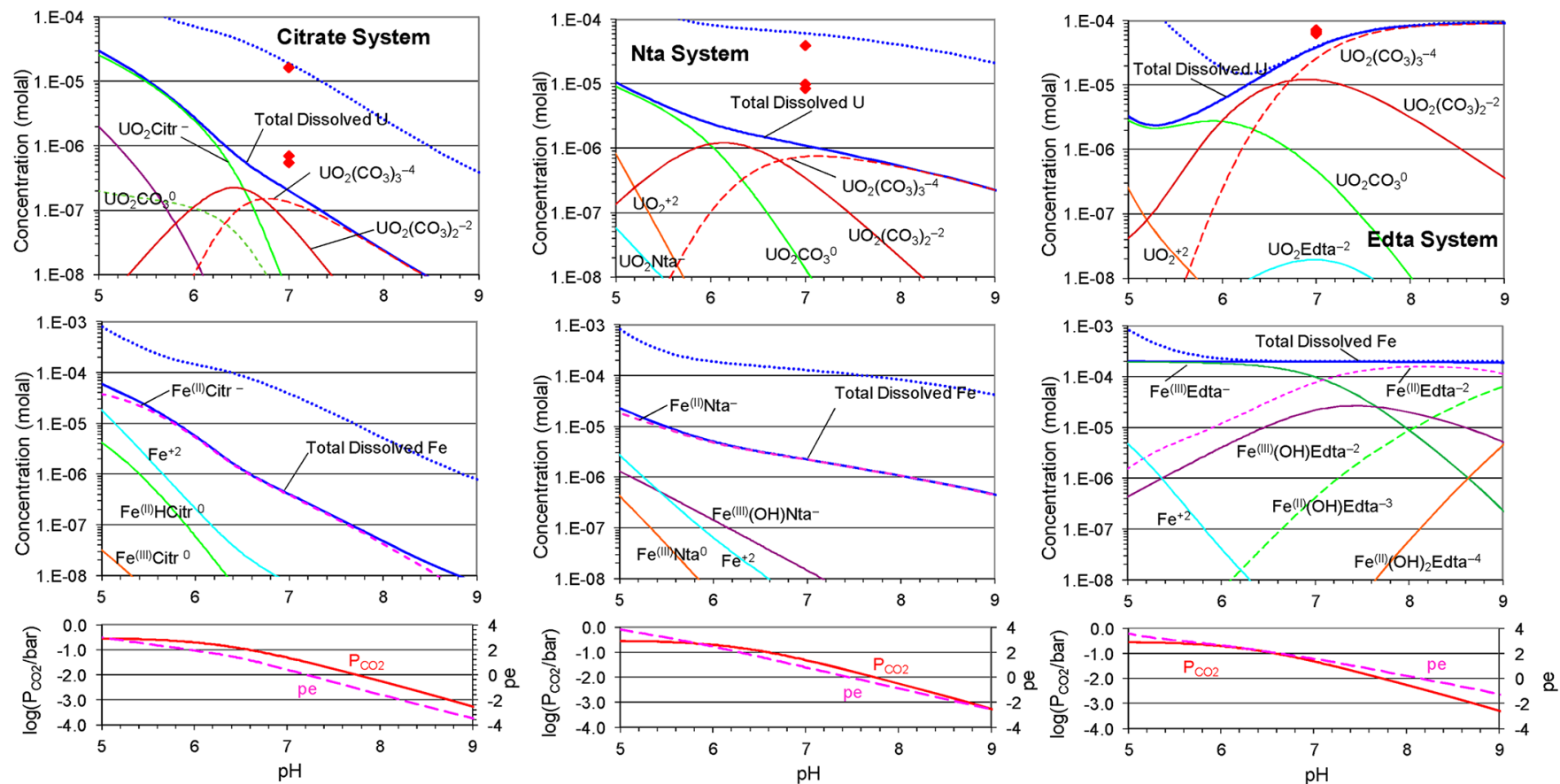

Figure 7. Simulated uraninite (as $\mathrm{UO}_{2}(\mathrm{cr})$ ) reoxidation by hematite $\left(\right.$ as $\mathrm{Fe}_{2} \mathrm{O}_{3}(\mathrm{cr})$ ) in systems containing $0.2 \mathrm{mM}$ of either citrate, NTA, or EDTA, and $10 \mathrm{mM} \mathrm{KHCO}$ at equilibrium, showing resulting $\mathrm{U}$ and $\mathrm{Fe}$ speciation, redox conditions (pe) and solution $\mathrm{CO}_{2}$ partial pressure $\left(\mathrm{P}_{\mathrm{CO} 2}\right)$ as a function of $\mathrm{pH}$. Symbols represent experimental $\mathrm{U}$ solubilities at $\mathrm{pH} 7$ for systems containing either hematite (lowest values), goethite, or ferrihydrite (highest values). Dotted lines represent computed total dissolved $U$ and Fe concentrations for systems containing ferrihydrite instead of hematite, resulting in mostly similar speciation (not shown for clarity).

tions. Also, the computed total dissolved $\mathrm{U}$ concentrations at $\mathrm{pH} 7$ for the hematite and ferrihydrite systems encompass measured concentrations reasonably well, given the fact that these concentrations span ranges of one or more orders of magnitude depending on $\mathrm{pH}$ and the type of $\mathrm{Fe}(\mathrm{III})$ solid involved. It should be noted that simulations for a system without chelators were also conducted and indicate solubilities about 1 order of magnitude lower than in the citrate system. Modeling results including input thermodynamic data are further discussed in the Supporting Information.

Implications for U Mobility. Our results reveal important $\mathrm{UO}_{2}$ reoxidation mechanisms that appear to depend on the thermodynamic stability of chelating agents primarily with $\mathrm{Fe}(\mathrm{III})$ and $\mathrm{Fe}(\mathrm{II}) . \mathrm{UO}_{2}$ reoxidation with $\mathrm{DFB}$ was inhibited with ferrihydrite and was undetectable with goethite or hematite, most likely as the result of strong DFB-Fe(III) complexes tying up soluble $\mathrm{Fe}$ (III) available for reaction. Such $\mathrm{Fe}(\mathrm{III})$ chelated species were predicted to play an insignificant role with the other chelators, except for EDTA at $\mathrm{pH}<6.5$. In contrast, progressively stronger complexes of citrate, NTA, and EDTA with $\mathrm{Fe}$ (II) appear to be driving the progressively more favorable reoxidation by these chelators. Thus, the rate and extent of dissolution of $\mathrm{Fe}$ (III) (hydr)oxides and complexation with $\mathrm{Fe}(\mathrm{II})$ are likely key mechanisms in $\mathrm{UO}_{2}$ reoxidation by $\mathrm{Fe}(\mathrm{III})$ (hydr)oxides. The rate of $\mathrm{UO}_{2}$ reoxidation by ferrihydrite increased with citrate (relative to no chelator), but the extent of reoxidation $(<15 \mu \mathrm{M})$ was not affected. Additionally, with citrate, no $\mathrm{UO}_{2}$ reoxidation occurred with goethite or hematite. The greatest initial rate and extent of $\mathrm{UO}_{2}$ reoxidation was observed with EDTA $(\sim 80 \mu \mathrm{M} \quad \mathrm{U}(\mathrm{VI})$ detected) and was independent of $\mathrm{Fe}(\mathrm{III})$ (hydr)oxide type. NTA had the next highest rate of reoxidation by ferrihydrite with approximately $50 \mu \mathrm{M} \mathrm{U}(\mathrm{VI})$ detected. Consistent with our experimental results and numerical simulations, strong $\mathrm{Fe}(\mathrm{II})$ chelators appear to promote the most reoxidation, whereas strong $\mathrm{Fe}(\mathrm{III})$ chelators actually promote $\mathrm{UO}_{2}$ stability. Note that if a chelator was able to facilitate the release of available $\mathrm{U}(\mathrm{IV})$ in solution, as suggested by our experimental results for the case of $\mathrm{UO}_{2}$ dissolution by NTA and EDTA without $\mathrm{Fe}(\mathrm{III})$, this could also be a primary contributor to $\mathrm{UO}_{2}$ dissolution. However, our modeling results suggest that when both $\mathrm{UO}_{2}$ and $\mathrm{Fe}(\mathrm{III})$ are present, chelated U(IV) does not play a significant role in the reoxidation. Additional studies involving more chelating agents (e.g., catechol, additional siderophore compounds) and varying $\mathrm{pH}$ values would help to expand on our understanding of these systems. These results demonstrate that it is critical to understand how complexing agents found at $U$ contaminated sites impact the stability of reduced $U$ minerals and ultimately help to predict the fate of $U$ in these settings.

\section{ASSOCIATED CONTENT}

\section{S Supporting Information}

XRD analysis, results from aqueous $\mathrm{Fe}$ (III)-chelator experiments, table of stability constants, and a more detailed thermodynamic analysis. This material is available free of charge via the Internet at http://pubs.acs.org. 


\section{ACKNOWLEDGMENTS}

We thank Tim Ginn for his valuable input on conceptual project design and interpretation of results. We also thank the Environmental Molecular Sciences Laboratory for imaging. This research was funded by the U.S. Department of Energy's Subsurface Biogeochemical Research program under Project No. DE-FG02-07ER-64366.

\section{REFERENCES}

(1) Wall, J. D.; Krumholz, L. R. Uranium reduction. Annu. Rev. Microbiol. 2006, 60, 149-166.

(2) Lloyd, J. R.; Lovley, D. R. Microbial detoxification of metals and radionuclides. Curr. Opin. Biotechnol. 2001, 12, 248-253.

(3) Langmuir, D. Uranium solution-mineral equilibria at lowtemperatures with applications to sedimentary ore-deposits. Geochim. Cosmochim. Acta 1978, 42, 547-569.

(4) Cochran, J. K.; Carey, A. E.; Sholkovitz, E. R.; Surprenant, L. D. The geochemistry of uranium and thorium in coastal marine sediments and sediment pore waters. Geochim. Cosmochim. Acta 1986, 50, 663680.

(5) Gavrilescu, M.; Pavel, L. V.; Cretescu, I. Characterization and remediation of soils contaminated with uranium. J. Hazard. Mater. 2009, 163, 475-510.

(6) Craft, E. S.; Abu-Qare, A. W.; Flaherty, M. M.; Garofolo, M. C.; Rincavage, H. L.; Abou-Donia, M. B. Depleted and natural uranium: chemistry and toxicological effects. J. Toxicol. Environ. Health, Part B 2004, 7, 297-317.

(7) Lovley, D. R.; Phillips, E. J. P.; Gorby, Y. A.; Landa, E. R. Microbial reduction of uranium. Nature 1991, 350, 413-415.

(8) Gorby, Y. A.; Lovley, D. R. Enzymatic uranium precipitation. Environ. Sci. Technol. 1992, 26, 205-207.

(9) Lovley, D. R.; Roden, E. E.; Phillips, E. J. P.; Woodward, J. C. Enzymatic iron and uranium reduction by sulfate-reducting bacteria. Marine Geology 1993, 113, 41-53.

(10) Ganesh, R; Robinson, K. G.; Reed, G. D.; Sayler, G. S. Reduction of hexavalent uranium from organic complexes by sulfateand iron-reducing bacteria. Appl. Environ. Microbiol. 1997, 63, 43854391.

(11) Beyenal, H.; Sani, R. K.; Peyton, B. M.; Dohnalkova, A. C.; Amonette, J. E.; Lewandowski, Z. Uranium Immobilization by SulfateReducing Biofilms. Environ. Sci. Technol. 2004, 38, 2067-2074.

(12) Frazier, S. W.; Kretzschmar, R.; Kraemer, S. M. Bacterial siderophores promote dissolution of $\mathrm{UO}_{2}$ under reducing conditions. Environ. Sci. Technol. 2005, 39, 5709-5715.

(13) Wan, J. M.; Tokunaga, T. K.; Brodie, E.; Wang, Z. M.; Zheng, Z. P.; Herman, D.; Hazen, T. C.; Firestone, M. K.; Sutton, S. R. Reoxidation of bioreduced uranium under reducing conditions. Environ. Sci. Technol. 2005, 39, 6162-6169.

(14) Suzuki, Y.; Suko, T. Geomicrobiological factors that control uranium mobility in the environment: Update on recent advances in the bioremediation of uranium-contaminated sites. J. Mineral. Petrol. Sci. 2006, 101, 299-307.

(15) Wilkins, M. J.; Livens, F. R.; Vaughan, D. J.; Lloyd, J. R. The impact of $\mathrm{Fe}$ (III)-reducing bacteria on uranium mobility. Biogeochemistry 2006, 78, 125-150.

(16) Finneran, K. T.; Anderson, R. T.; Nevin, K. P.; Lovley, D. R. Potential for Bioremediation of uranium-contaminated aquifers with microbial U(VI) reduction. Soil Sediment Contam. 2002, 11, 339-357.

(17) Gu, B. H.; Yan, H.; Zhou, P.; Watson, D. B.; Park, M.; Istok, J. Natural humics impact uranium bioreduction and oxidation. Environ. Sci. Technol. 2005, 39, 5268-5275.

(18) Sani, R. K.; Peyton, B. M.; Dohnalkova, A.; Amonette, J. E. Reoxidation of reduced uranium with iron(III) (hydr)oxides under sulfate-reducing conditions. Environ. Sci. Technol. 2005, 39, 20592066.

(19) Senko, J. M.; Mohamed, Y.; Dewers, T. A.; Krumholz, L. R. Role for $\mathrm{Fe}(\mathrm{III})$ minerals in nitrate-dependent microbial U(IV) oxidation. Environ. Sci. Technol. 2005, 39, 2529-2536.
(20) Wan, J. M.; Tokunaga, T. K.; Brodie, E.; Wang, Z. M.; Zheng, Z. P.; Herman, D.; Hazen, T. C.; Firestone, M. K.; Sutton, S. R. Reoxidation of bioreduced uranium under reducing conditions. Environ. Sci. Technol. 2005, 39, 6162-6169.

(21) Ginder-Vogel, M.; Criddle, C. S.; Fendorf, S. Thermodynamic constraints on the oxidation of biogenic $\mathrm{UO}_{2}$ by $\mathrm{Fe}(\mathrm{III})$ (hydr) oxides. Environ. Sci. Technol. 2006, 40, 3544-3550.

(22) Ulrich, K. U.; Singh, A.; Schofield, E. J.; Bargar, J. R.; Veeramani, H.; Sharp, J. O.; Bernier-Latmani, R.; Giammar, D. E. Dissolution of biogenic and synthetic $\mathrm{UO}_{2}$ under varied reducing conditions. Environ. Sci. Technol. 2008, 42, 5600-5606.

(23) Luo, W.; Gu, B. Dissolution and Mobilization of Uranium in a Reduced Sediment by Natural Humic Substances under Anaerobic Conditions. Environ. Sci. Technol. 2009, 43, 152-156.

(24) Ulrich, K. U.; Ilton, E. S.; Veeramani, H.; Sharp, J. O.; BernierLatmani, R.; Schofield, E. J.; Bargar, J. R.; Giammar, D. E. Comparative dissolution kinetics of biogenic and chemogenic uraninite under oxidizing conditions in the presence of carbonate. Geochim. Cosmochim. Acta 2009, 73, 6065-6083.

(25) Ginder-Vogel, M.; Stewart, B.; Fendorf, S. Kinetic and mechanistic constraints on the oxidation of biogenic uraninite by ferrihydrite. Environ. Sci. Technol. 2010, 44, 163-169.

(26) Nevin, K. P.; Lovley, D. R. Potential for nonenzymatic reduction of $\mathrm{Fe}(\mathrm{III})$ via electron shuttling in subsurface sediments. Environ. Sci. Technol. 2000, 34, 2472-2478.

(27) Sani, R. K.; Peyton, B. M.; Amonette, J. E.; Geesey, G. G. Reduction of uranium(VI) under sulfate-reducing conditions in the presence of $\mathrm{Fe}(\mathrm{III})$ (hydr)oxides. Geochim. Cosmochim. Acta 2004, 68, 2639-2648.

(28) Suzuki, Y.; Tanaka, K.; Kozai, N.; Ohnuki, T. Effects of citrate, NTA, and EDTA on the reduction of U(VI) by Shewanella putrefaciens. Geomicrobiol. J. 2010, 27, 245-250.

(29) Haas, J. R.; Northup, A. Effects of aqueous complexation on reductive precipitation of uranium by Shewanella putrefaciens. Geochem. Trans. 2004, 5, 41-48.

(30) Dodge, C. J.; Francis, A. J. Biotransformation of binary and ternary citric acid complexes of iron and uranium. Environ. Sci. Technol. 1997, 31, 3062-3067.

(31) Senko, J. M.; Kelly, S. D.; Dohnalkova, A. C.; McDonough, J. T.; Kemner, K. M.; Burgos, W. D. The effect of U(VI) bioreduction kinetics on subsequent reoxidation of biogenic U(IV). Geochim. Cosmochim. Acta 2007, 71, 4644-4654.

(32) Luo, W.; Gu, B. Dissolution of uranium-bearing minerals and mobilization of uranium by organic ligands in a biologically reduced sediment. Environ. Sci. Technol. 2011, 45, 2994-2999.

(33) Hummel, W.; Anderegg, G.; Puigdomenech, I.; Rao, L. F.; Tochiyama, O. The OECD/NEA TDB review of selected organic ligands. Radiochim. Acta 2005, 93, 719-725.

(34) De Stefano, C.; Gianguzza, A.; Milea, D.; Pettignano, A.; Sammartano, S. Sequestering ability of polyaminopolycarboxylic ligands towards dioxouranium(VI) cation. J. Alloys Compd. 2006, 424, 93-104.

(35) Cornell, R. M.; Schwertmann, U. The Iron Oxides: Structure, Properties, Reactions, Occurences, and Uses; Wiley-VCH: Weinheim, Germany, 2003.

(36) Spycher, N.; Issarangkun, M.; Stewart, B.; Sengor, S.; Belding, E.; Ginn, T.; Peyton, B. M.; Sani, R. K. Biogenic uraninite precipitation and its reoxidation by iron(III) (hydr)oxides: A reaction modeling approach. Geochim. Cosmochim. Acta 2011, 75 (16), 4426-4440.

(37) Wolin, E. A.; Wolin, M. J.; Wolfe, R. S. Formation of methane by bacterial extracts. J. Biol. Chem. 1963, 238, 2882-\&.

(38) Brooks, S. C.; Taylor, D. L.; Jardine, P. M. Reactive transport of EDTA-complexed cobalt in the presence of ferrihydrite. Geochim. Cosmochim. Acta 1996, 60, 1899-1908.

(39) Atkinson, R. J.; Posner, A. M.; Quirk, J. P. Adsorption of potential-determining ions at ferric oxide-aqueous electrolyte interface. J. Phys. Chem. 1967, 71, 550-\&. 
(40) Schwertmann, U.; Cornell, R. M. Iron Oxides in the Laboratory Preparation and Characterization, 2nd ed.; Wiley-VCH: Weinheim, Germany, 2000; pp 123-124. 